\title{
The Effect of Contextual Approach and Learning Motivation on Students Skills in Writing News Text
}

\section{Yetty Morelent', Ineng Naini ${ }^{1}$, and Rippi Hamdani²}

${ }^{1}$ Lecturer of Indonesian Language and Education Study Program, Teacher Training and Education Bung Hatta University.

${ }^{2}$ Student of Master of Indonesian Language Education Study Program, Bung Hatta University

\section{Abstract}

This study aims to find out: (1) differences in the increase in learning outcomes of news text writing skills between low and high motivated students taught with contextual and conventional learning; and (2) the effect of learning approaches and learning motivation on news text writing skills. This study was a quasi-experimental design with nonequivalent control group design. The population in this study were all students of

Corresponding Author:

Yetty Morelent

morelent104@yahoo.com

Received: 18 January 2019

Accepted: 24 March 2019

Published: 31 March 2019

Publishing services provided by

Knowledge E

(c) Yetty Morelent et al. This

article is distributed under the

terms of the Creative Commons

Attribution License, which

permits unrestricted use and

redistribution provided that the

original author and source are

credited.

Selection and Peer-review under the responsibility of the First ELEHIC Conference Committee. class XII Islamic Senior High School 1Pekanbaru, with the total number of 331 students. Cluster sampling technique was used.Thirty students in each class XII MIA 1 was used as the experimental class and class XII MIA 3 as the control class. Based on the data analysis, the results revealed at the 95\% level of confidence that: (1) Students' news text writing skill taught using a contextual approach is significantly higher than the students taught using conventional approaches because when learning using a contextual approach students are seen to respond well (2) the increase in low motivated students news text writing skills was significantly higher than students who were taught using conventional approaches because with the contextual approach students can understand learning well (3) the increase in high motivated students news text writing skills was significantly higher than students who were taught using conventional approaches because with the contextual approach students can understand learning well because high motivated students were s more active when they were taught using contextual approach, and (4) there is an interaction between learning approaches and student motivation in influencing the writing skills of Year 12 students because motivation to learn can determine the success in student writing skills. Thus the contextual approach can be used as an appropriate learning approach to improve students' writing ability.

Keywords: writing skills, motivation, writing news texts, contextual approaches 


\section{Introduction}

The development of science and technology requires someone to have the skills to enable them to keep up with the times. Education institutions must be able to anticipate these developments by continuing to strive for a program that is in accordance with the development of students, the their age, situation, conditions, and needs. One of the skills needed by students is writing news. The skilss of writing news text is considered very necessary because nowadays information is one of the important needs of human life.

Writing news is a skill that requires a thinking process and needs the $5 \mathrm{~W}+1 \mathrm{H}$ elements. These elements answer the question what (what happens), who (who is involved in the event), why (why did it occur), where (where is the place), when (when it happened), and how (how / how it happened). This $5 \mathrm{~W}+1 \mathrm{H}$ element needs to be understood by students in writing news. However, learning how to write especially writing news text is difficult for students, because most students think that writing is a difficult, and boring activity that causes students to be less interested. Some students tend to have difficulty in developing ideas in written form. This is evident from the low results of news text writing skills that are under the minimum score required by the school, which was 75 .

The test results revealed that students have difficulty in writing news texts. They were not able to develop the headlines into sentences. They were also not able to compile news texts in accordance with the news writing technique namely upside pyramid pattern. Students were confused to start a sentence. Students were less willing to ask questions, they just stayed quiet when asked for their opinions.

Based on the results of interviews with students, several factors that cause students to be less able to write were identified. One of them is unintersting teaching method used by the teacher $\mathrm{g}$ so students feel bored. It was difficult for them to start writing and they were also not motivated to learn to write. In addition, the results of observations also indicated that the teacher still used the old method of teaching. The method used by the teacher made students less active and the learning process becomes monotonous.

From the observations, it can be seen that students were not able to write news sections such as deadlines, leads, news bodies, and tails, and they were also been able to compile the headlines. In addition, many students' writings were far from the standard of the correct news writing. This can be seen in the aspects assessed in the news, such as the compatibility of the contents of the news, the completeness of the news elements, the systematics of news writing, language, and spelling.

In addition, the weakness also lies with the teacher, that there are still many teachers who use approaches that are not suitable for learning material. This problem is evident 
in the learning process and its implementation, old traditions in teaching are often still found in the world of education. In other words, the teacher still uses a conventional approach in teaching Indonesian language. There are still many teachers who only want convey knowledge to students. On this basis, many teachers choose lecturing techniques, giving assignments, and exercises in delivering material to students. Consequently learning becomes monotonous, less stimulating the development of potential children, less motivating children to achieve, thus results inthe low competence of students.

The process of teaching is only limited to explaining the learning material of writing news texts, after which students are told to directly write the news. After completion, the results of student work are collected and corrected by the teacher. Teacher gives the score and return the paper to the students. These habits ultimately influence the ability of students to write.

This problem needs to be addressed by the teacher by applying innovative learning models. Many innovative learning models that are standardized in the implementation of the 2013 curriculum are: (1) problem based learning; (2) project based learning; (3) discovery / inquiry learning models; and (4) learning models through contextual approaches that can provide refreshment for students in following the teaching and learning process.

One approach in innovative learning that can be combined with learning to write news is a contextual approach (CTL). The contextual approach is a teaching approach that emphasizes the involvement of students to find learning material and connect them with the lives and experiences of students in their environment, and its application in the community. The contextual approach places students as the subject of learning, and the teacher can also innovate in linking learning to writing news texts in relation to students' real-life so that students it is easier for students to understand learning. This is also stated by [1] that learning in the classroom with the use of contextual approaches makes students totally involved and more active in the lesson. The contextual approach has advantages when compared to the conventional approach. These advantages include contextual learning which places students as subjects of learning. Teachers can also innovate by relating it to learning to write news texts in relation to students' real life so that students can understand learning and it will be more fun.

The problem of the ability to write news text is also experienced by students of class XII Islamic Seinor High School 1 Pekanbaru. These problems also relate to the approach used by the teacher. For this reason, research on news text writing skills needs to be conducted. 
The objectives of the study are to examine: (1) the increase in the results of writing news texts of students who learn using a contextual approach and students who were taught using obtained the conventional approach; (2) the increase in the results of news text writing ability of low motivated students taught using contextual approach and and conventional approach; (3) an increase in news text writing ability for students who have high motivation taugh using contextua and conventional approach; (4) explain the interaction between learning approaches and learning motivation in influencing students' news text writing skills.

\section{Theoritical Review}

The theory of the contextual approach used is [2] and [3] theory. The components that must be present in contextual learning are (1) making meaningful links; 2) doing meaningful work; (3) conduct self-regulated learning; (4) work together; (5) critical and creative thinking; (6) helping individuals to grow and develop; (7) achieving high standards; (8) use authentic assessment. The learning component is a foundation that must be present in the application of a contextual approach. The reason researchers use this theory is because it fits the needs and problems in this study.

In learning motivation, according [4]. at motivated students have the following characteristics: (1) diligently facing the task (can work continuously for a long time, never stop before completion); (2) resilient in facing difficulties; (3) showing interest in various problems; (4) prefer to work alone; (5) get bored quickly on routine tasks (recurring things); (6) can maintain his opinion; (7) it is not easy to let go of what is believed; and (8) happy to find and solve problems of problems.

The theory used for news writing is the one proposed by [5]. The elements that must be in present in writing news are what, where, when, who, why and how. In addition, the structure of the news folows an inverted pyramid system. Using this, the writing is more easily understood by readers. The parts of the inverted pyramid are headlines, date lines or timelines, news terrace or Lead (intro), $5 \mathrm{~W}+1 \mathrm{H}$ elements, news body: principal elements of $5 \mathrm{~W}+1 \mathrm{H}$, tail news / punch. This theory is in accordance with the teaching of writing news texts taught at school.

\section{Methodology}

This research is a quasi-experimental research design or design used is nonequivalent control group design. According to [6], quasi-experiment is a design that has a control 
group, but it cannot function as completely as controlling external variables that influence the implementation of experiments. It is explained in the following table:

TABLE 1: Nonequivalent Control Group Design.

\begin{tabular}{|l|l|l|l|}
\hline Experiment class: & $\mathbf{0 1}$ & $\mathbf{X}$ & $\mathbf{0 2}$ \\
\hline Control Class: & $\mathbf{0 3}$ & & $\mathbf{0 4}$ \\
\hline source: Sugiyono (2016) [6] & & & \\
\hline
\end{tabular}

Information.

$\mathrm{X}=$ Provision of treatment

$\mathrm{O} 1=$ Value of the initial test of the experimental class

$\mathrm{O} 2=$ Value of the final test of the experimental class

$\mathrm{O} 3=$ Value of the initial test of the control class

$\mathrm{O} 4=$ Value of the final test of the control class

The population in this study were students of Year 12 of an Islamic Senior High School In Pekanbaru in the 2017/2018 school year. The number of students participated in this study was s 331 students. The research sample is taken by cluster sampling technique with the area specified in the sampling is in the natural Science Department. The samples were 30 students in each class as the experimental class and another class as the control class.

This study consisted of three variables. First, the independent variable; is the variable that causes changes to the dependent variable. As an independent variable in this study is a contextual model (CTL). Second, the dependent variable is a variable that is influenced by the independent variable. In this study, the dependent variable is news text writing skills. Third, the moderator variable is a variable that strengthens the relationship between the independent variable and the dependent variable. The moderator variable in this study is student motivation.

The data in this study were motivation scores, scores of the news text writing skills test using the contextual approach (experimental class) and conventional (control class). Motivation data were collected through questionnaires before being given treatment, while data on news text writing skills were collected before and after the treatment given.

Analysis of data gathered from questionnaires is conducted in the following procedures: first, reading questionnaires that have been filled by students; second, checking each question contained in the questionnaire whether there is one that is not filled by students, if it is not filled out, it will be excluded from the research data; third, giving a score on each questionnaire question that has been identified; fourth, adding the total 
score of the question; fifth, sort the questionnaire scores starting from the highest score to the lowest score; sixth, dividing students' learning motivation into two groups, $50 \%$ in the upper group and $50 \%$ in the group under [7].

While the performance test is conducted in the following way, namely: First, read the text of the news text that has been written by the student as a whole; second, identify whether the text of the news is included in the research data or not; third, give a score on the writing in accordance with the indicators studied. Fourth, change the score to value based on the PAP (Benchmark Reference Assessment). To change the score to value, the formula used is the percentage formula. The percentage formula aims to determine the level of mastery of students' skills in writing news text.. Kent, describes the frequency distribution of students' news text writing skills tests; seventh, displaying data in the form of histograms; eighth, before the hypothesis testing is carried out, the requirements test of the research hypothesis is carried out, namely the test data is normally distributed and has a homogeneous variance. Next to test the hypothesis with the formula independent t-test and specifically to see the interaction, the data were analyzed using two-way analysis of variance (ANOVA).

\section{Results and Discussion}

\subsection{Student news text writing skills taught with contextual approaches and conventional approaches}

Based on descriptive analysis, there are differences between pre-test and post-test skills in writing news texts in the class of contextual approaches with conventional approach classes, each of which has increased. In addition, the posttest and pre-test results of students 'news text writing skills in the contextual learning class is higher than in writing news text writing skills in conventional learning classes.

Based on the testing of hypothesis 1 using the independent sample $t$-test, the hypothesis 1 tested was the average score of news text writing skills of students taught using a contextual approach was significantly higher than students taught using conventional approaches.

TABLE 2: Results of Analysis of the Testing of the First Hypothesis.

\begin{tabular}{|c|c|c|c|c|c|c|c|c|}
\hline No & Sample & $N$ & $\mathbf{S}_{g a b}$ & $\propto$ & $\mathrm{dk}$ & $\mathrm{t}_{h}$ & $\mathrm{t}_{t}$ & \\
\hline 1 & Experiment Class & 30 & 11,27 & 0,05 & 58 & 7,48 & 2,021 & Accepted $\mathrm{H}_{1}$ \\
\hline 2 & Control Class & 30 & & & & & & \\
\hline
\end{tabular}


Based on table 1 , it is reaveled that the resulting $t_{-}=7.48$ while $t$ _table $=2.021$ so that $\mathrm{HO}$ is rejected and $\mathrm{H} 1$ is accepted. It means that students' skills in writing news text taught by using contextual approach was signlificantly higher than difference those taught using conventional approach.

The results of the study are in line with the research carried out by other researchers. First, [8] with the title "Application of Contextual Approaches in Learning to Write News (Experimental Study in Class VIII Students of Cianjur Middle School 1)". The results showed an effective contextual approach in learning to write news of class VIII students of SMAN 1 Cianjur. In addition, [9] with the title, "Learning to Write News Text by Using the Contextual Teaching And Learning (CTL) Method in Class XII Vocational Students". The results of the study showed that with the modeling technique on CTL students were motivated to learn so that the ability to write news texts in class XII in vocational school could be improved.

Similar study previous revealed that there was an increase in student learning outcomes in news text writing skills using a contextual approach. However, the studies did not show the increase students, but only focused on students' final score. In addition, the study only focused on the influence of learning motivation that can affect the results of student writing skills.

The improvement in students skills in writing when taught by using a contextual approach is in line with [3] who states that contextual approach is a learning approach that emphasizes the involvement of students to find material and connects them with the lives and experiences of students in their environment. It also teaches its application in society by involving students fully in the learning process. The topics discussed can arouse new desires and interests so that students' understanding and ability in writing news texts increase.

\subsection{News text writing skills of low motivated students taught using contextual approaches and conventional approaches}

Based on descriptive analysis, there were differences between pre-test and post-test results of writing skills of low motivated students' in the class taught using contextual approaches and conventional approach. Each of which experienced an increase. In addition, the difference between the posttest and pre-test results of the news text writing skills of low motivated students in the contextual learning class is higher than the results of the news text writing skills of low motivated students in the experimental class. 
The second hypothesis tested the average results of the news text writing skills of students who had low motivation by using independent t-test. It was revealed that students who were taught using a contextual approach had significantly higher socre than those taught using a conventional approach.

TABLE 3: Results of Analysis of Testing of the Second Hypothesis.

\begin{tabular}{|l|l|c|c|c|c|c|c|l|} 
No & Sampel & $\mathbf{N}$ & $\mathbf{S}_{g a b}$ & $\alpha$ & $\mathbf{d k}$ & $\mathbf{t}_{h}$ & $\mathbf{t}_{t}$ & Keterangan \\
\hline 1 & Experiment Class & 15 & 8,09 & 0,05 & 28 & 6,99 & 2,048 & Accepted $\mathrm{H}_{1}$ \\
\hline 2 & Control Class & 15 & & & & & & \\
\hline
\end{tabular}

Based on table 2, it is found that the resulting t_h was 6.99 and t_t was 2.048 , so HO was rejected and $\mathrm{H} 1$ was. It means that low motivated students's news text writing skills taught using a contextual approach was higher than students who were taught using a conventional approach.

Contextual learning can make low-motivated students who are used to passivity in the classroom become more active, because it is associated with real life that makes students motivated to learn and pay attention to learning. This is in line with [10] who stated that contextual learning is a learning concept that helps teachers associate material taught with real-world situations of students by encouraging students to make connections between their knowledge and the application in their lives as family members and community.

\subsection{News text writing skills of highly motivated students taught using contextual approaches and conventional approaches}

Based on descriptive analysis, there are differences between pre-test and posttest results of highly-motivated students' in the class of contextual approaches and conventional approach classes. Each of which has increased. In additionr difference between the posttest and pre-test results of news text writing skills of highly motivatited students taught using contextual learning was higher than the results of the news text writing skills of highly motivated students in the experimental class.

The third hypothesis tested the average results of the news text writing skills of students who were highly motivated taught using a contextual approach. The results revealed that there was significantly higher than highly moivated students taught by using a conventional approach.

Table 3 shows that there was a significant difference between news text writing skills of highly motivated students taught using a contextual approach and conventional 
TABLE 4: Results of Analysis of Testing of the Third Hypothesis.

\begin{tabular}{|l|l|l|c|c|c|c|c|c|}
\hline No & Sample & $\mathbf{N}$ & $\mathbf{S}_{g a b}$ & $\propto$ & $\mathbf{d k}$ & $\mathbf{t}_{h}$ & $\mathbf{t}_{t}$ & Note \\
\hline 1 & Experiment Class & 15 & 12,91 & 0,05 & 28 & 2,36 & 2,048 & Accepted $\mathrm{H}_{1}$ \\
\hline 2 & Control Class & 15 & & & & & & \\
\hline
\end{tabular}

appeoach. Contextual learning can make motivated students can be more active in class, because there are 7 components of learning that are well implemented by students during four learning meetings. The seven components of contextual learning as presented by [11]. Contextual learning is a learning approach which has seven principles (components), namely: (1) constructivism; (2) inquiry; (3) ask; (4) learning community; (5) modeling; (6) reflection, (7) real assessment.

\subsection{Interaction between learning approaches and learning moti- vation on news text writing skills}

The fourth hypothesis in this study which was tested by using two-way ANAVA. It was revealed that there was a significant interaction between learning approaches and learning motivation towards the results of news text writing skills. It can be interpreted that each factor in learning approach and learning motivation depends on each other in influencing students' writing text news skills.

TABLE 5: The Results of the Fourth Hypothesis Testing.

\begin{tabular}{|l|l|c|c|c|c|c|} 
No & Source & $\begin{array}{c}\text { Number of } \\
\text { Square }\end{array}$ & $\begin{array}{c}\text { Average } \\
\text { JK }\end{array}$ & \multicolumn{2}{|c|}{$F$} \\
\hline & & & & & Calculated & Table \\
\hline 1 & Between row & 1983,75 & 1 & 1983,75 & 21,585 & 4,02 \\
\hline 2 & Between Columns & 1000,417 & 1 & 1000,417 & 10,885 & 4,02 \\
\hline 3 & Interactions & 510,417 & 1 & 510,417 & 5,554 & 4,02 \\
\hline 4 & Error & 5146,67 & 56 & 91,905 & & \\
\hline
\end{tabular}

Based on table 4 the results of the calculation of two-way ANAVA for testing the fourth hypothesis and based on the calculation it was found that the Interaction $=5.554>\mathrm{F}$ table (4.02) with a real level $(\alpha=0.05)$. It can be interpreted that there is an interaction between the learning approach used and student learning motivation in influencing the ability to write news texts on Indonesian language subjects. That is, the fourth $\mathrm{H} 1$ is accepted and verified as in the following interaction graph. 


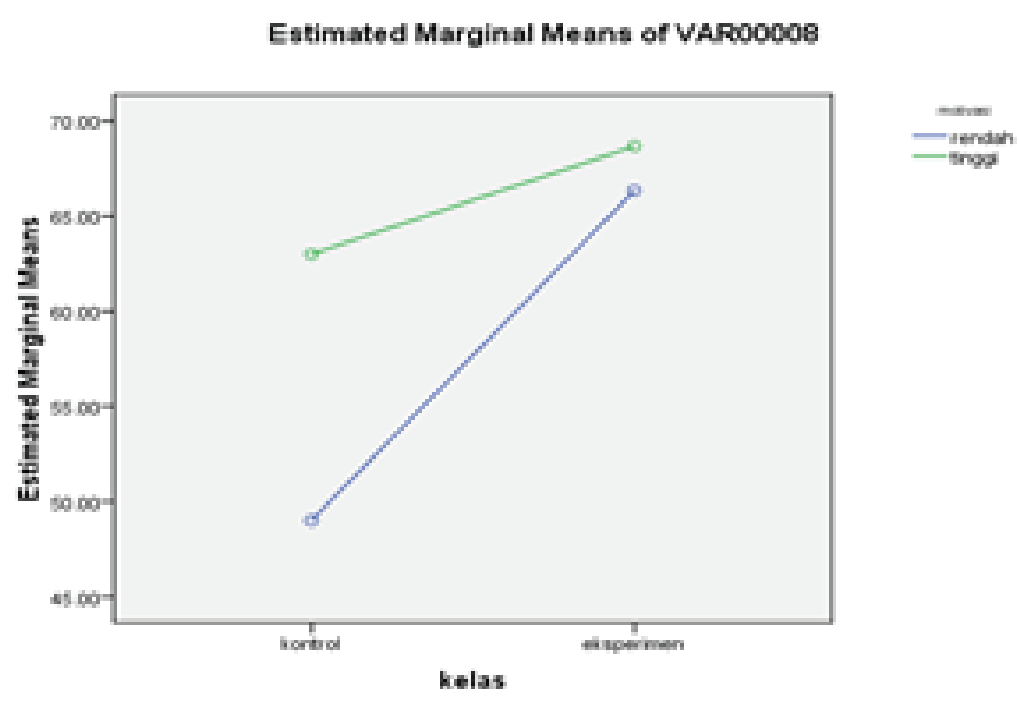

Graph of Interaction Between Learning Approaches and Student Learning Motivation on News Text Writing Skills

Based on the graph in Figure 1, the two lines are not parallel. This is in line with the opinion of Minium, et al. (1993) that there is an interaction between learning and student motivation and each factor has a significant effect. In other words, the learning and motivation categories together have a significant influence on the results of students' news text writing skills. The results of this study are in line with the results [12], namely on the interaction of contextual learning strategies with achievement motivation on the ability to write descriptive essays of class VIII SMP students in Ngawi.

This means that learning motivation can fully determine success in writing skills, in addition to other factors that affect such as learning styles, intelligence, abilities and so on. Contextual tend to be more effectively applied to both categories of student learning motivation. The results of the students' writing text skills in the experimental class taught with the contextual approach appear to be higher descriptively. The difference in results between students with low and high motivation is not much different than the control class taught with a conventional approach.

This can be seen based on contextual learning carried out in the experimental class. Observations indicated that students who have low learning motivation show activeness in learning because real life based learning is done by students. While students who have high motivation also show the same activity because there are 7 components of learning that make learning not monotonous. In conventional learning carried out in the control class, students are seen to study. 


\section{Conclusions and Recommendations}

Conclusions of this study are as follows: (1) Students skills in writing news taught using contextual approaches is significantly higher than students taught using conventional approaches (2) News text writing skills of low motivated students taught using a contextual approach is significantly higher than low motivated students taught using conventional approaches (3) News text writing skills of highly motivated students taught using a contextual approach is significantly higher than students who have high learning motivation who taught using conventional approaches; (4) There is an interaction between the learning approach used and student learning motivation in influencing the skills of writing news texts on Indonesian subjects.

While the interpretative conclusions of this study are as follows: (1) Students taught using a contextual approach has better ability than the students who use the conventional approach in class XII Islamic Senior High School in Pekanbaru; (2) For students with low motivation, teaching them with contextual approach it is better than students' ability to use conventional approaches; (3) Similarly, students who have high learning motivation teaching them by using a contextual approach to news text writing skills, is better than students using conventional approaches to class XII Islamic senior high school in Pekanbaru; (4) There is an interaction between the learning approach used and learning motivation towards the ability to write news. Based on conclusions, it can be recommended that a contextual approach is proven to improve news text writing skills. Indonesian teachers can apply creative, innovative learning through a contextual approach.

\section{References}

[1] Subaweh, A. M. 2016. "Penerapan Pendekatan Kontekstual dalam Pembelajaran Menulis Teks Berita pada Siswa Kelas VIII MTs Nurul Huda Kalibuntu Kecamatan Losari”. Jurnal Penelitian Pendidikan Indonesia. Vol. 7. No. 3B. Halaman 40.

[2] Johnson, Elaine B. 2014. Contextual Teaching and Learning. Bandung: Mizan Media Utama.

[3] Komalasari, Kokom. 2014. Pembelajaran Kontesktual Konsep dan Aplikasi. Bandung: Reflika Aditama.

[4] Sardiman, A.M. 2011. Interaksi dan Motivasi Belajar Mengajar. Jakarta: Raja Grapindo Persada.

[5] Panggabean, Wahyudi El. 2007. Strategi Wartawan. Pekanbaru: Forum Kerakyatan. 
[6] Sugiyono. 2016. Metode Penelitian Pendidikan. Bandung: Alfabeta.

[7] Arikunto, Suharsimi. 2006. Prosedur Penelitian Suatu Pendekatan Praktik. Jakarta: Rineka Cipta.

[8] Alpiah. 2014. "Penerapan Pendekatan Kontesktual dalam Pembelajaran Menulis Berita Studi Eksperimen pada Siswa Kelas VIII SMAN 1 Cianjur". Tesistidak diterbitkan. Bandung: Sekolah Pascasarjana Universitas Pendidikan Indonesia.

[9] Hadiana, Ade. 2016. "Pembelajaran Menulis Teks Berita dengan Menggunakan Metode Contextual Teaching And Learning pada Peserta Didik kelas XII SMK". Jurnal Pendidikan Bahasa dan Sastra Indonesia.Vol. 2.No.5. Halaman 3.

[10] Rosalin, Elin. 2008. Gagasan Merancang Pembelajaran Kontesktual. Bandung: Karsa Mandiri Persada.

[11] Hamruni. 2011. Strategi Pembelajaran. Yogyakarta: Ihsan Madani.

[12] Waraulia, Asri Wasandi. 2016. "Pengaruh Strategipembelajaran Kontekstual Dan Motivasi Berprestasi Terhadap Kompetensi Menulis Deskripsi Siswa SMP Kelas VIII". Jurnal Widyasastra. Vol. 04. No 2.Halaman 185. 